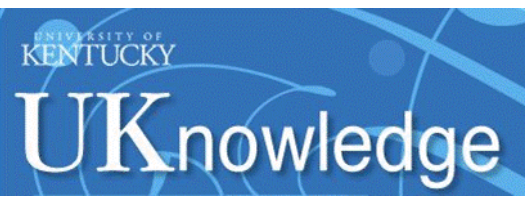

University of Kentucky

UKnowledge

\title{
The Allocation and Exchange of Property Rights as a Way to Understand Comparative Economics Systems and Managerial Economics
}

John Garen

University of Kentucky, john.garen@uky.edu

Follow this and additional works at: https://uknowledge.uky.edu/isfe_papers

Part of the Economics Commons

Right click to open a feedback form in a new tab to let us know how this document benefits you.

\section{Repository Citation}

Garen, John, "The Allocation and Exchange of Property Rights as a Way to Understand Comparative Economics Systems and Managerial Economics" (2019). Institute for the Study of Free Enterprise Working Papers. 5.

https://uknowledge.uky.edu/isfe_papers/5

This Research Paper is brought to you for free and open access by the Institute for the Study of Free Enterprise at UKnowledge. It has been accepted for inclusion in Institute for the Study of Free Enterprise Working Papers by an authorized administrator of UKnowledge. For more information, please contact UKnowledge@lsv.uky.edu. 


\title{
The Allocation and Exchange of Property Rights as a Way to Understand Comparative Economics Systems and Managerial Economics
}

\section{John Garen}

$$
\text { July } 2019
$$

Institute for the Study of Free Enterprise Working Paper 25

\author{
University of Kentucky \\ 244 Gatton College of Business and Economics \\ Lexington, KY 40506-0034 \\ http://isfe.uky.edu/
}




\title{
The Allocation and Exchange of Property Rights as a Way to Understand Comparative Economics Systems and Managerial Economics
}

\author{
John Garen* \\ BB\&T Professor of Economics \\ Gatton College of Business and Economics \\ University of Kentucky \\ jgaren@uky.edu
}

July 2019

This paper discusses how economic systems can be described by the manner that property rights are allocated to individuals, to the government, or to interests groups. Property rights entail control of use of assets, claim on the net income from an asset, and transferability of the previous two. Economics systems (e.g., capitalism, socialism, cronyism) are characterized by who holds these rights, in whole or in part, and this determines the success or failure of an economy. A related analysis is applied to understanding business organization, e.g., the corporate and noncorporate form, franchising, and employee compensation methods. Each entails a (voluntary) allocation of the three aspects of property rights to different individuals and each has benefits and costs. Several examples are discussed. Competition selects the most efficient form of organization. This illustrates the importance of the private ownership of property rights, where parties may trade and divide them, for the success of businesses and the economy as a whole.

*For support, I wish to thank the Institute for the Study of Free Enterprise at the University of Kentucky. 


\section{Introduction}

This paper analyzes comparative economics systems and managerial economics with a unifying theme of the allocation and exchange of property rights. It is argued that all economic systems, e.g., capitalism, socialism, and so on, are understood as different ways in which three basic aspects of property rights are allocated. Additionally, we discuss how the allocation of the same three aspects of property rights are at the core of much of managerial economics.

Section II of the paper describes the three aspects of property rights: control over use of assets, claim on the net income (or enjoyment) from the assets, and transferability (alienability) of the previous two. Section III of the paper examines a number of economic systems and shows how each is described by the manner in which property rights are allocated. So, for example, in a capitalist system, each of the above noted aspects of property rights are held predominately by individuals (or their designees). With socialism, these rights are largely held by the government. In welfare states, such as those in the Scandinavian countries, these rights are divided, where the government (through taxation) holds much of the rights to income. In part A of section IV, the importance of the private ownership of property is discussed, with focus on how it enables unifying decision-making rights over how assets are used on one hand, with incentives and relevant knowledge on the other.

Part B of section IV works through a number of examples on how private owners may divide the three aspects of property rights. Examples include corporations, franchising, and employee compensation. Each organizational form divides property rights differently and the nature of the division characterizes the organization. Each has its benefits and costs and, in a competitive market, those that are most efficient survive and thrive. This further illustrates the 
importance of private ownership of each aspect of property rights, with competition among different styles of organizations. Lastly, section V concludes.

\section{What Are Property Rights?}

The terms "property rights" and "ownership” are often used interchangeably and indeed are closely linked. Ownership of a good or asset - whether the asset is physical, intangible, brainpower, etc. - consists of three rights. This is equivalent to property rights. ${ }^{1}$ These three rights are below.

1. Control of over use of the good or asset. Owners decide how assets are deployed. There is the presumption that each owner's deployment does not interfere with another owner's. Otherwise, one's deployment partly determines another's, in contradiction to this aspect of ownership.

2. Claim on the residual income (e.g., net income) from an asset or the enjoyment from use of the asset. Owners have claim on the net income from the asset or may enjoy its use.

3. Transferability (alienability) of the above two rights. Owners may sell the rights of control and of residual claims. They may divide each of them into parts and/or divide them from one another. Also, transferability itself may be retained or sold by owners.

Thus, to say that you "own" an asset is to say that you control how it is used, have claim on income produced and/or non-pecuniary enjoyment from the asset, and may sell either of the above two. Consider several examples to illustrate these rights may be sold or divided. These are in the context of individual ownership of these rights since this a familiar setting. One example is where owners of firms sell common stock. This is the sale of residual income claims

\footnotetext{
${ }^{1}$ These aspects of property rights are discussed in several places in the literature. See, for example, Alchian (undated), Alchian and Allen (1969), and Blair (1995).
} 
(right 2) with very little, if any, control rights (right 1). Managers retain most control rights. If the stock is traded on an exchange, stockholders have transferability of right 2 . Another example is the following. Those who loan a lot of money (i.e., buy large amounts of debt) to a small firm may also require that they be awarded some decision-making power in the firms they invest in. Thus some control rights are transferred, but not residual claims since debt requires a fixed payment, not a share of the net residual income. Consider yet another example. In privatelyheld corporations, those who become owners gain some control rights and residual claims, but the purchase agreement may restrict reselling these rights. Thus, transferability is restricted. Thus, even though rights 1 through 3 are in private hands, they may be voluntarily separated. There are various reasons why organizations divide ownership in various ways and some of the basics are discussed below. ${ }^{2}$

The same basic ideas apply to human resources as well, though there are some differences. Buyers of labor services essential rent the skill sets and brainpower of the workers in question for a specified time and rate. In many employment settings, employees cede the right to direct their deployment to employers, within certain bounds. Employees sometimes contract for part of the residual claims from the use of their services, though often do not. For example, there may be profit sharing, commissions, and piece work. Human assets are not directly bought and sold, but there is transferability. By quitting and taking another job, a worker transfers the control and residual claims due to his/her skills from one employer to another. Firms that raid another's employees accomplishes the same thing. If one firm acquires another, the control rights and residual claims from extant human resources are transferred to the acquiring firm. Also, workers

\footnotetext{
${ }^{2}$ Regarding rights of control, Grossman and Hart (1986) make a noteworthy distinction between contractual rights and residual rights. The latter are non-contractible control rights. Both refer to the same element of ownership though.
} 
may decide to be self-employed and direct their own efforts and retain residual claims. Thus, even with labor services, there is a substantial aspect of transferability.

\section{The Division of Property Rights Defines Economic Systems}

All economic systems allocate rights 1 through 3 in various ways. Each is characterized by the way these rights are allocated. Here, a number of leading examples are discussed.

Capitalism. Rights 1 through 3 are privately held. A single individual may hold all three or they may be contractually divided among multiple private parties. However, they remain privately held.

Note that it is difficult to have $100 \%$ private ownership. With capitalism, the establishment and enforcement of the above rights requires property and contract law that are understood and largely accepted by parties. The first - property law - determines an accepted set of rules about which private party owns what. The second - contract law - are rules that guide how private transfers/trades are made. Many advocates of a capitalist economy indicate that this is the role of government. Naturally, some level of taxation and government expenditure is required for a government to undertake these functions. Taxation makes a claim on the income from assets, both human and non-human. Thus, even a capitalist system does not allocate all of right 2 (residual claims) to individuals.

There are situations where property rights are difficult to define, enforce, and trade ${ }^{3}$ A typical example is environmental pollution. Failing to resolve this with use of property rights

\footnotetext{
${ }^{3}$ Demsetz (1967) indicates that property and contract law will emerge only if the resources in question are scarce enough so their value exceeds the cost of establishing and enforcing relevant law. Thus, for some goods, ownership may be ill-defined even in a capitalist setting.
} 
generates externalities. In this setting, governments might step in to control use of pollutiongenerating assets even in a largely capitalist economy.

A strong form of capitalism is that rights 1 through 3 are presumed to be held by individuals and removed from individuals only in special circumstances, such as in the example of environmental pollution or in the cases of theft, violence, or fraud. In the latter cases, individuals engaging in those acts violate the property rights of others, so might be punished by fines or imprisonment. These entail loss of individual residual claimancy and control rights. However, in the strong form of capitalism, government is empowered to do this only if there is demonstrable violation of another's rights.

A weak form of capitalism is the presumption that rights 1 through 3 may be awarded to individuals with permission from government and the government, in turn, allows individuals to hold these rights. This is a weak form because of capitalism since the power to remove rights 1 through 3 fundamentally gives government underlying control of those rights.

Political economy/public choice considerations determine whether government has the limited powers in the strong form of capitalism or the greater powers of the weak form and, in the latter case, how those powers are exercised.

Socialism. Rights 1 through 3 are held by a central authority, i.e., "the government.” This authority determines how assets are used, who has claim on production and use, and how these may be transferred across individuals.

This is the polar opposite case of capitalism. Here, individuals hold none of these rights and the government holds them all. Generally, this entails some form of central planning of the 
output and distribution of goods and services, of the allocation of resource inputs, and of prices, wages, and incomes.

As above, $100 \%$ government ownership is not achievable. Governments cannot feasibly control all uses of assets. For example, equipment and land might be surreptitiously utilized by farmers and manufacturers for personal use. Human capital can be privately directed by neglecting official duties and working for personal gain. ${ }^{4}$ Also, black markets may emerge where individuals determine trades and income claims.

Presumably, socialism can take various forms. Authoritarian socialism is where the government holds rights 1 through 3 with absolute power and with no legal restraints.

Communism is where private ownership is abolished and ownership is awarded to a specific collective entity; the proletariat. Whatever form of government that emerges from "the proletariat” holds rights 1 through 3 . It is thought that socialism can emerge from a democratic/majoritarian process as well; i.e., democratic socialism. ${ }^{5}$ This presumably occurs where a pluralistic voting process opts for government ownership of rights 1 through 3 . Of course, there is no guarantee that a pluralistic voting process would support socialism. Also, in each of these, the specific political/economic forces at play determine what form of socialism (or other economic system) occurs.

Fascism. Rights 1 through 3 are held by a ruling group of major entities in the economy and society; the government, big business associations, and major labor unions. Decisions are made by the group, though the government makes final approval of the decisions.

\footnotetext{
${ }^{4}$ The issue of diverting asset use away from that desired by the owner is a problem confronted by capitalist owners as well. This is an issue of enforcing property and contract rights and pervades all transactions, regardless of the economic system.

${ }^{5}$ This differs from "social democracy," which is discussed below.
} 
Decision making authority is awarded to industrial associations and labor unions regarding production, prices, and wages. Thus, use of assets and income claimancy are determined by these groups, and so it seems that private parties hold property rights. However, this is largely an illusion. One reason is that decisions must be approved by the government. Thus, fundamentally, the government controls production, prices, and wages and so indirectly holds rights 1 through 3 . The government may approve the business associations' and unions' plans and allow private decision makers to get their way, giving the appearance of private ownership. However, the power of government to negate those decision means that government holds the rights. This is a case where the presumption is that the rights are held by the government, but may be granted to others.

A second reason why this system is illusory private ownership is the following. Even if the private associations and unions are allowed by the government to implement their plans, this does not enable general private holding of rights. If an entrepreneur wishes to use his/her assets to enter a market and produce a good or services, the government prevents it since is does not follow the approved plan. Similarly, attempts by companies to cut prices, or by workers to accept lower wages, are thwarted by the government. Thus, individuals are not allowed to control use of their assets nor to gain income for those uses. The private holding of rights is not upheld generally.

The Welfare State. This is characterized by very high levels of taxation that support very high levels of subsidization of certain goods, typically food, housing, education, medical care, and leisure. Private control of assets is largely retained, as is transferability. However, claims on net income is deeply abrogated due to the high levels of taxation. 
While rights 1 and 3 largely remain in place, the attenuation of right 2 - residual income claimancy - removes a great deal of the incentive to effectively create and deploy assets (e.g., to invest and work), as well as to seek out value-increasing asset transfers. If income claimancy is eroded enough, there is little to be gained by efficiently exercising rights 1 and 3 . This scenario is often blamed for the persistent low economic growth of many European countries that proximate the welfare state.

Sweden, and a host of other countries, have adopted welfare state-like economies and one often hears question, “Is Sweden socialist?" The above analysis implies that the answer is "no" since rights 1 and 3 are still largely in private hands. However, it is clear that Sweden - and countries with similar economic systems - removes a great deal of the right to residual income claims from individuals and awards it to government.

The term "social democracy" is often used almost synonymously with the term "welfare state.” However, most modern definitions of social democracy indicate that the term also entails a good deal of regulation of the private sector. ${ }^{6}$ This involves government activity beyond enforcement of privately held rights and private contracts. It may potentially include government control or influence over pricing, employment, wages, production, and entry into markets. Note, though, that these latter items pertain to how assets are used and transferred. Thus, as the scope of government regulation grows and deepens in these respects, it becomes more and more like government ownership of rights 1 and 3.

Interventionism. This is a term coined by von Mises (2008) that is little used, but captures a good deal of government activity that occurs. It refers to a host of partial and piecemeal

\footnotetext{
${ }^{6}$ See, for example, https://en.wikipedia.org/wiki/Social democracy. Also, there is a political dimension to modern definitions, i.e., that there is a pluralistic voting process to select political leaders.
} 
government controls over markets, firms, workers, and consumers. These include government entry barriers, wage and price controls, limits on profits, interest rate restrictions, regulations, taxes, subsidies, and tariffs and quotas. Each represents moving some aspects of rights 1 through 3 from individuals to government.

Consider the case of barriers to entry into markets. This prevents potential entrants from deploying their assets to serve certain markets. Thus, some individual control of asset use is lost. Wage, price, and interest rate controls disallow some private transactions to transfer assets/goods, thus remove parts of rights of transfer from individuals. Regulations impinge on individual rights to use assets and to engage in trade/transfers. Profit limitations reduce individual income claimancy. Tariffs and quotas limit individual rights to trade/transfer assets with foreign parties. The effects of these policies and other government interventions have been fruitfully analyzed, but the point here is that each entails altering the allocation of rights 1 through 3.

Cronyism. This term is often not carefully defined. Essentially, though, it refers to the case where a select group of government “cronies” has control or influence regarding the determination of rights 1 through 3.

An extreme form of cronyism is the fascist economic model, where big business and large labor unions have a dominant influence over production, distribution, prices, and wages. Though government must approve these plans, rights 1 through 3 are not held by individuals, but by the "cronies" and the government. Less extreme forms of cronyism are cases where cronies have a strong influence over specific government policies. This includes the case of powerful special interest groups that influence the host of government polices noted under 
interventionism, e.g., entry barriers, favorable regulation, taxes, subsidies, and so on. Cronies have, indirectly, a degree of control of these policies. Thus, they gain rights 1 through 3 in partial and piecemeal ways. Those who are not cronies partially lose these rights.

There are other economic systems one might consider, as well as hybrids of the above. In each case, which system emerges depends on political economy/public choice considerations in each particular setting. ${ }^{7}$ This paper does not explain which system occurs where. But regardless of the system, it can be characterized by which parties gain rights 1 through 3 . Capitalism is the only system where individuals hold these rights. In all others systems, to one degree or another, they are attained by a ruling or politically influential group.

\section{Property Rights and Economic and Business Organization Success}

A great deal has been written about the success or failure of economic systems and of individual organizations. Part A of this section reviews some underlying principles to understand this, illustrating the importance of property rights and the success or failure of economic systems. Part B provides several examples to show how the private allocation of the above three rights is often the key to a business organization's success.

\section{A. Property Rights and Economic System Success}

Regarding economic organization, Hayek (1945) emphasized the importance of combining decision rights over the use of assets on one hand, with knowledge of the situation on the other. He noted that a great deal of knowledge is imbedded in particular circumstances and is not easily transmitted to third parties. Thus, in order to utilize the relevant knowledge to allocate assets efficiently, decision making must be devolved/decentralized to those "on the spot." This is Hayek’s (1945) essential argument as to why government central planning results in poor

${ }^{7}$ A related and intermingled issue is the how the political system emerges, e.g., an authoritarian rule or majority driven. 
outcomes - the central planners making the decisions cannot obtain a great deal of the relevant information.

This line of argument is expanded upon by Jensen and Meckling (1992) where they incorporate the importance of incentives. They argue that decision rights, incentives, and knowledge are ideally united (or co-located, to use their term) in order to attain efficient asset use. The basic idea is that if those who decide how assets are used also have the relevant knowledge as well as the appropriate incentives, then assets are likely to be used efficiently.

Jensen and Meckling (1992) indicate that markets tend to unite decision rights, incentives, and relevant knowledge. Note the close relationship to property rights 1 through 3. Decision rights regarding how assets are used is right 1 . Transferability (right 3 ) entails that those who are the most knowledgeable about specific markets can acquire the assets that they are knowledgeable about. Residual claims (right 2) provides the incentive to do these in valueincreasing ways. This illustrates a further contrast with centrally planned economies. Central planners typically have neither the knowledge of particular circumstances about how assets should be used, nor the incentives to allocate them effectively. These are the essential reasons why market economies outperform centrally planned ones. ${ }^{8}$ Moreover, the same logic applies to situations where control of rights 1 through 3 are removed from private parties on a piecemeal basis, such as with entry restrictions, price controls, taxes, and subsidies. The end result is poorer economic performance in those markets where this occurs.

Though markets tend to unite decision authority, knowledge, and incentives, they also allow private parties to divide them. This is accomplished by using right 3 (rights to transfer) to

\footnotetext{
${ }^{8}$ This has been studied a great deal. For example, see O’Driscoll and Hoskins (2003) on the importance of good private property rights for economic development. Also, private property rights are an important element of economic freedom indices and the latter has been shown to be important for economic prosperity. See, for example, Gwartney, et. al. (2018).
} 
engage in exchanges of rights 1 and 2. Though there are strong forces to unite ownership of rights 1 through 3 - thereby uniting decision rights, incentives, and knowledge - private ownership also enables them to separate. An important and interesting issue is why private parties would separate these rights.

\section{B. Organizational Form and Dividing Property Rights}

Jensen and Meckling (1992) and Fama and Jensen (1983a,b) discuss conditions under which separation or division of decision rights from incentives and/or knowledge might occur. This implies dividing rights 1 through 3 . There are various ways to do this and the manner in which it is done often implicitly describes different organizational forms. Some work well in certain circumstances and others in different circumstances. Those organizational forms that work well provide the good or service in question at lower cost and/or provide something of higher value to the consumer. In a competitive world, these organizations will outcompete organizational forms that do a lesser job in these respects. Thus, the benefits of dividing rights 1 through 3 must outweigh the costs in specific situations. Otherwise, firms that do so would not survive.

This implies that a key to good management - and long-term survival in a competitive marketplace - is selecting the appropriate organizational form that suits the particular situation. Indeed, if management fails to do so, the competitive process will implicitly do so by replacing inefficient firms with efficient ones. Below are discussions of several examples of organizational forms, how they divide rights 1 through 3, and why they may be efficient in certain circumstances.

Sole Proprietorship. This is where rights 1 through 3 are held by a single individual. Clearly, this unites decision rights and incentives. Those with the most relevant knowledge about a 
market settings have strong incentives to acquire the decision rights and residual claims regarding assets they are most knowledgeable about. This brings the relevant knowledge together with decision rights and incentives. Small private partnerships are similar to proprietorships except that rights 1 through 3 are held by a small group of individuals.

Corporations. Consider that the large, publically traded corporation in this example. Here, decision rights over the use of assets are (mostly) separated from claims on residual income. Managers of big corporations hold most of the decision rights and stockholders hold most of the residual claims. This division of rights separates, to a significant degree, decision rights from incentives. Managers who deploy assets have the everyday knowledge of the companies they manage, but do not feel most of the effects of their decisions. Their decisions affect the stock price and it is mostly the stockholders who enjoy the benefits or bear the costs of changes in the stock price caused by managers. Thus, manager incentives are abated and agency costs are incurred. ${ }^{9}$ This has been recognized for a long time and its modern analysis was launched by Jensen and Meckling (1976). They point out that there must be a reason for diluting the incentives of managers. Doing so incurs agency costs, so there must be more-than-offsetting benefits. There are several possibilities for this. For example, if a lot of capital is required for efficiency, one can draw upon many people as shareholders who have funds to invest but no expertise in management of the firm in question. Those with expertise but limited funds can remain as managers. Thus, it may be worthwhile to incur some agency costs of the large corporate form if the greater efficiency from the additional capital is more than offsetting.

\footnotetext{
${ }^{9}$ There is a substantial literature analyzing practices that might limit these agency costs or restore manager incentives. These include manager performance bonuses, boards of directors to monitor managers, and corporate takeovers. For discussion, see Fama and Jensen (1983b).
} 
A successful business will adopt the corporate form if this holds and will not if it doesn’t. A competitive economy with privately held property rights thus incentivizes finding the most efficient business form.

As an aside, consider the term "the separation of ownership and control” that is often used to describe large corporations. This misleading terminology. Control is an aspect of ownership and is not distinct from it. Those who use this term are really referring to the separation of residual claims from control of asset use. The key questions in this literature are: (i) whether the benefit of separating the two is worth the cost, and; (ii) whether private parties are enabled to make those calls, which are then put to the market test. Under a capitalist system, private parties are enabled to make those calls and are incentivized to make decisions where the benefits exceed the costs.

Franchising. This is another case where rights 1 through 3 are divided. Franchisees typically get a substantial share of the residual income from the franchise unit, but not all. Franchisees have decision rights over some things (e.g., personnel, day-to-day operations) but the franchisor has control over others (e.g., equipment, business routine, branding). Franchisees may transfer their rights by selling the franchise, though typically only with approval by the franchisor.

This division/separation of rights generates benefits as well as costs. Granting decision rights to franchisees over day-to-operations makes sense since they have the necessary everyday operational knowledge. Similarly, franchisors likely have the relevant knowledge of brand building and the business routine and so have decision authority in those respects. Thus, parties have decision rights over things that they know best. This unites knowledge and decision authority. But how can one unify incentives with knowledge and decision rights? An important way to incentivize franchisees is to allow them to keep a large share of the net income of the 
franchise unit they operate. ${ }^{10}$ However, a large share for franchisees means a lower share for the franchisor, thereby abating the latter's incentives. Ultimately, the division of net income depends on which party's incentives are most important, as well as other factors. ${ }^{11}$

The overarching point, however, is the following. Franchising is a system of transferring some degree of claim on net income and some decision rights to franchisees, with the franchisor retaining some. In a competitive setting, businesses that adopt this organizational form will succeed only if the benefits exceed the costs, i.e., it is more efficient than alternatives. Private ownership of the three aspects of property rights 1 through 3 enables businesses to select this, or other, organizational forms.

Workplace Organization and Compensation. Employee work routines and methods of compensation may differ greatly. For example, offsite sales personnel are often compensated by commissions and allowed set their own hours. In this setting, they likely have the best knowledge of how to make sales, know the best work routines to follow, and are rewarded for successfully doing so. Knowledge, decision rights (to some degree), and incentives are united. However, there are employees for which it is not feasible to do so. Consider the example of office clerical staff. They are usually paid by salary or by the hour. It is usually difficult to develop good, direct incentives in this setting. Do you reward keystrokes typed on memos and letters, number of calls taken, or similar criteria? These are problematic since they measure only quantity and not the quality or value of the work done. Thus, direct incentives do not work. Since there are no strong incentives, it is not sensible to award decision rights to employees over their hours, work routine, and equipment use. The costs of awarding decision rights to clerical

\footnotetext{
${ }^{10}$ Rubin (1978) was the first to analyze franchising in the context of the provision of incentives.

${ }^{11}$ For empirical evidence in this regard, see Wimmer and Garen (1997).
} 
staff exceeds the benefits because they cannot be properly incentivized. The inability to unify incentives with knowledge implies that decision rights are held by another party. The same ideas apply in other job settings. ${ }^{12}$

An organization will achieve greater success if it is able to determine the appropriate decision authority and incentives for its employees. This is, in effect, transferring property rights in an efficient way. Competitive markets with private ownership of rights 1 through 3 enables and incentivizes this to happen. The successful organization finds the compensation methods, work routines, and employee decision authority where the benefit exceeds the costs.

There are numerous other examples of business practices that involve dividing or uniting decision rights, incentives, and knowledge. Examples include establishing exclusive territories for retailers, use of resale price maintenance, use of joint ventures, financial cooperatives, and nonprofit organizations. This paper does not attempt to analyze each of these, but in each, the above ideas apply. ${ }^{13}$ There are costs and benefits of uniting or dividing decision rights, knowledge, and incentives. Privately held rights in a competitive setting induce organizations to choose those for which the benefits exceed the costs.

\section{Conclusion}

The analysis of property rights has proven to be an extremely fruitful approach to understanding a great deal about economic systems and business organizations. This paper reiterates the meaning of property rights/ownership - entailing control of use, claim on residual income, and transferability - and illustrates how it is a unifying theme that defines economic systems. How property rights are allocated to individuals, to government, or to selected interest

\footnotetext{
${ }^{12}$ See Holmstrom and Milgrom (1994) for a theoretical presentation of these ideas and Garen (2004) for related empirical work.

${ }^{13}$ For excellent discussions of these and related business practices, see Rubin (1990) and Fama and Jensen (1983a).
} 
groups - in whole or in part - essentially defines an economic system. Indeed, capitalism, socialism, and the host of hybrids between those two can be characterized by who holds these rights. Moreover, as emphasized by many authors, the allocation of property rights to private individuals versus government is a key to economic prosperity.

A related analysis applies the same reasoning to business organizations. This paper illustrates how various business practices unify or separate decision rights, incentives, and knowledge and that this is determined by the allocation of property rights to different individuals. Each allocation has different benefits and costs and so is important in determining the success of an organization. Competitive markets ferret out business practices that do not pass the benefit/cost test. Thus, competition and private ownership of property, where owners are enabled to divide ownership, are keys to business success, which ultimately translates into success for the economic system. 


\section{References}

Alchian, Armen, “Property Rights,” The Liberty of Economics and Liberty (undated), https://www.econlib.org/library/Enc/PropertyRights.html.

Alchian, Armen and Allen, William, Exchange and Production: Theory in Use, Wadsworth Publishing Company, Inc., Belmont, CA, 1969.

Blair, Margaret, Ownership and Control, Brookings Institution, Washington, DC, 1995.

Demsetz, Harold, “Toward a Theory of Property Rights,” American Economic Review, 57(2), May 1967, pp. 347-359.

Fama, Eugene and Jensen, Michael, “Agency Problems and Residual Claims,” Journal of Law and Economics, 26(2), June 1983a, pp. 327-349.

Fama, Eugene and Jensen, Michael, “Separation of Ownership and Control,” Journal of Law and Economics, 26(2), June 1983b, pp. 301-325.

Garen, John, "Independent Contractors and Self-Employment as Systems of Incentives and Control: Theory, Empirics, and a Survey of Evidence,” Research in Labor Economics, vol. 23, 2004, pp. 27-68.

Grossman, Sanford J. and Hart, Oliver D., "The Costs and Benefits of Ownership: A Theory of Vertical and Lateral Integration. Journal of Political Economy, 94(4), May 1986, pp. 691-719.

Gwartney, James; Lawson, Robert; Hall, Joshua; and Murphy, Ryan, Economic Freedom of the World, 2018 Annual Report, Fraser Institute, 2018, https://www.fraserinstitute.org/sites/default/files/economic-freedom-of-the-world-2018.pdf.

Hayek, Friedrich A. (1945), “The Use of Knowledge in Society,” American Economic Review, 35(4), September 1945, pp. 519-530.

Holmstrom, Bengt and Milgrom, Paul, “The Firm as an Incentive System,” American Economic Review, 94(4), September 1991, pp. 972-991,

Jensen, Michael and Meckling, William, 'Theory of the Firm: Managerial Behavior, Agency Costs, and Ownership Structure,” Journal of Financial Economics, 3(4), October 1976, pp. 305360.

Jensen, Michael and Meckling, William, "Specific and General Knowledge, and Organizational Structure”, in Werin, Lars and Wijkander, Hans (Eds), Contract Economics, Blackwell, Cambridge, MA, 1992, pp. 251-274.

O’Driscoll, Gerald and Hoskins, Lee, "Property Rights: The Key to Economic Development,” Cato Institute Policy Analysis No. 482, August 2003, https://object.cato.org/sites/cato.org/files/pubs/pdf/pa482.pdf. 
Rubin, Paul, "The Theory of the Firm and the Structure of the Franchise Contract," Journal of Law and Economics, 21(1), April 1978, pp. 223-233.

Rubin, Paul, Managing Business Transactions, The Free Press, New York, NY, 1990.

“Social Democracy,” https://en.wikipedia.org/wiki/Social_democracy.

Von Mises, Ludwig, "Planning for Freedom," in Planning for Freedom: Let the Market System Work, Liberty Fund, Indianapolis, IN, 2008, pp. 3-14.

Wimmer, Bradley and Garen, John, "Moral Hazard, Asset Specificity, Implicit Bonding, and Compensation: The Case of Franchising,” Economic Inquiry, 35(3), July 1997, pp. 544-554. 